\title{
Originals
}

\section{Glycosylation of low density lipoprotein in patients with Type 1 (insulin-dependent) diabetes: correlations with other parameters of glycaemic control}

\author{
T. J. Lyons ${ }^{1}$, J. W. Baynes ${ }^{2}$, J. S. Patrick ${ }^{2}$, J. A. Colwell ${ }^{1}$ and M. F. Lopes-Virella ${ }^{1}$ \\ ${ }^{1}$ Department of Medicine, VA Medical Center and Medical University of South Carolina, Charleston, and \\ ${ }^{2}$ Department of Chemistry, University of South Carolina, Columbia, South Carolina, USA
}

Summary. Glycosylation of low density lipoproteins obtained from 16 patients with Type 1 (insulin-dependent) diabetes and from 16 age-, sex-, and race-matched controls, was determined. The diabetic patients were normolipaemic and were in good or fair glycaemic control. Eleven patients performed home blood glucose monitoring. Glycosylation of low density lipoproteins in the diabetic patients was significantly higher $(p<0.001)$ than in the control subjects, and was significantly correlated with haemoglobin $\mathrm{A}_{1 \mathrm{c}},(p<0.01)$, glycosylation of plasma proteins, $(p<0.001)$, and mean home blood glucose, $(p<0.01)$. This study confirms that, in diabetic patients, increased glycosylation of low density lipoprotein occurs to an extent which correlates closely with other commonly used indices of glycaemic control.

Key words: Diabetes, low density lipoproteins, glycosylation.
Increased non-enzymatic glycosylation [1] has been demonstrated in many circulating and tissue proteins in diabetes [2]. Since lipoproteins are intimately involved with the development of atherosclerosis, the major cause of morbidity and mortality in diabetic patients [3], any modification of lipoprotein particles occuring in the diabetic state is of considerable interest. Studies using low density lipoprotein (LDL) glycosylated in vitro have demonstrated that the modified lipoprotein is degraded less rapidly than control LDL by human fibroblasts grown in tissue culture $[4,5]$. This may explain the increased levels of circulating LDL usually found in poorly controlled diabetic patients. However, the conditions of in vitro glycosylation used in these studies were likely to result in much higher levels of glycosylation than those occuring in vivo. Although a similar effect on LDL degradation by fibroblasts was also observed when lesser degrees of in vitro glycosylation were studied [6], the clinical significance of these findings is unclear because the extent of glycosylation occuring in vivo in typical diabetic patients has not been investigated in detail. In this study, we have compared the degree of glycosylation of LDL from a group of Type 1 (insulindependent) diabetic patients, in good or fair glycaemic control, with that of LDL from a matched non-diabetic control group. We have related LDL glycosylation to other parameters of recent glycaemic control - haemoglobin $\mathrm{A}_{1 \mathrm{c}}$, glycosylation of plasma proteins and the results of home blood glucose monitoring.

\section{Subjects and methods}

Sixteen patients were recruited from the Private Diagnostic Clinic of the Medical University of South Carolina. All had Type 1 diabetes mellitus diagnosed according to the criteria established by the National Diabetes Data Group [7]. For every diabetic patient, an age-, sex-, and race-matched non-diabetic control was recruited from the staff at the Medical University of South Carolina, and blood was drawn on the same day from each member of the matched pair. One patient/ control pair was studied on two separate occasions when the diabetic member was in good and poor glycaemic control $\left(\mathrm{HbA}_{1 \mathrm{c}} 6.3\right.$ and $10.1 \%$ respectively). Of the 16 diabetic patients, 11 performed home blood glucose monitoring, and were asked to provide measurements of blood glucose taken four times daily (before meals) during the week prior to blood sampling. Seven patients had evidence of background retinopathy and three had evidence of neuropathy. Three patients and one control were receiving thyroxine therapy for hypothyroidism but were clinically euthyroid, one patient and two controls were taking diuretics (furosemide or thiazide) and one control a $\beta$ blocking agent. One diabetic patient and her corresponding control were in the third trimester of pregnancy. Additional characteristics of the diabetic and control groups, including weight, age, sex, and racial distribution are shown in Table 1.

A 60-ml sample of venous blood was collected from all subjects after a $12-14 \mathrm{~h}$ fast and before the morning insulin dose to isolate $\mathrm{LDL}$ and to measure plasma glucose, $\mathrm{Hb}_{\mathrm{A} 1 \mathrm{c}}$, plasma lipid and lipoprotein levels.

Informed consent, as approved by the Institutional Review Board of the Medical University of South Carolina, was obtained from all subjects involved in the study.

\section{LDL isolation}

$\operatorname{LDL}(1.019<\mathrm{d}<1.063 \mathrm{~g} / \mathrm{ml})$ was isolated from plasma at $15^{\circ} \mathrm{C}$ by sequential ultracentrifugation [8] in a Beckman 50 Ti rotor (Beckman In- 
Table 1. Clinical characteristics of diabetic and control subjects

\begin{tabular}{|c|c|c|c|c|c|c|}
\hline & $\begin{array}{l}\text { Sex } \\
M: F\end{array}$ & $\begin{array}{l}\text { Race } \\
\text { B:W }\end{array}$ & $\begin{array}{l}\text { Age } \\
\text { (years) }\end{array}$ & $\begin{array}{l}\text { Body mass } \\
\text { Index }\end{array}$ & $\begin{array}{l}\text { Duration of } \\
\text { diabetes (years) }\end{array}$ & Insulin: $\mathrm{U} / \mathrm{kg}$ body wt. \\
\hline $\begin{array}{l}\text { Diabetic patients } \\
(n=16)\end{array}$ & $6: 10$ & $1: 15$ & $\begin{array}{l}33.5 \pm 1.9 \\
(20-49)\end{array}$ & $\begin{array}{c}23.2 \pm 0.8 \\
(16.4-28.1)\end{array}$ & $\begin{array}{l}13.9 \pm 2.1 \\
(3-33)\end{array}$ & $\begin{array}{c}0.71 \pm 0.09 \\
(0.39-1.90)\end{array}$ \\
\hline $\begin{array}{l}\text { Control subjects } \\
(n=16)\end{array}$ & $6: 10$ & $1: 15$ & $\begin{array}{l}32.6 \pm 2.1 \\
(24-53)\end{array}$ & $\begin{array}{c}24.1 \pm 1.0 \\
(18.6-35.9)\end{array}$ & - & - \\
\hline$p$ & - & - & NS & NS & - & - \\
\hline
\end{tabular}

Values expressed as mean $\pm 1 \mathrm{SEM}$ (range); NS = not significant

struments Inc, Palo Alto, Calif, USA). Salt solutions used to adjust plasma densities contained 0.01\%(w/v) EDTA, pH 7.4. Isolated LDL was washed and concentrated by recentrifugation at the appropriate density in a Beckman SW55Ti rotor (Beckman Instruments Inc, Palo Alto, Calif, USA). After determination of protein concentration by the Lowry method [9], aliquots of the washed LDL fraction were adjusted to a concentration of $1 \mathrm{mg} / \mathrm{ml}$ and frozen at $-70^{\circ} \mathrm{C}$ for later determination of glycosylation.

\section{Plasma proteins}

For each subject two millilitres of fresh plasma containing $0.01 \%$ EDTA was stored at $-70^{\circ} \mathrm{C}$ for later determination of glycosylation.

\section{Measurement of glycosylation of LDL and plasma proteins}

Glycosylation of LDL and plasma proteins was determined by affinity chromatography, using a method similar to that employed by Yue et al. [10] in the measurement of tissue protein glycosylation. Stored LDL samples were thawed and aggregated lipoproteins were dispersed by brief $(<5 \mathrm{~s})$ sonication (probe-sonicator, Heat SystemsUltrasonic Inc, Plainview, NY, USA). Stored plasma samples were thawed and $1 \mathrm{ml}$ of each was diluted by adding $4 \mathrm{ml}$ of $0.9 \%(\mathrm{w} / \mathrm{v})$ $\mathrm{NaCl}$ solution containing $0.01 \%(\mathrm{w} / \mathrm{v})$ EDTA. One millilitre of the diluted plasma was dialysed overnight at $4^{\circ} \mathrm{C}$ against a large excess of saline/EDTA to remove free glucose, and its protein concentration was determined by the Lowry method [9]. A $200 \mu 1$ aliquot of the LDL sample $(200 \mu \mathrm{g}$ protein) or a $14-\mu \mathrm{l}$ aliquot of the plasma protein sample (approximately $200 \mu \mathrm{g}$ protein) made up to $200 \mu \mathrm{l}$ with saline/ EDTA, was added to $250 \mu \mathrm{l}$ sodium carbonate buffer $\left(0.2 \mathrm{M} \mathrm{Na}_{2} \mathrm{CO}_{3}\right.$, adjusted to $\mathrm{pH} 9.0$ ) and $50 \mu 11 \%$ sodium dodecyl sulfate (SDS) in a teflon-lined screw-topped test tube. Ketoamine-linked glucose adducts were reduced and radio-labeled by addition of $20 \mu \mathrm{l}$ of tritiated sodium borohydride $(5 \mathrm{mCi} / \mathrm{ml}, 360 \mathrm{mCi} / \mathrm{mmol}$, New England $\mathrm{Nu}$ clear, Boston, Mass, USA) followed by incubation for $1 \mathrm{~h}$ on ice and $3 \mathrm{~h}$ at room temperature. It was determined that these conditions produced maximal incorporation of tritium in the glycosylated protein, and that tritium incorporation was linearly related to the amount of protein present when up to $400 \mu \mathrm{g}$ protein were used. Excess tritium was discharged by the addition of an equal volume $(520 \mu \mathrm{l})$ of $12 \mathrm{~N}$ hydrochloric acid, and acid hydrolysis was carried out for $18 \mathrm{~h}$ at $95^{\circ} \mathrm{C}$ [11]. To minimize losses and experimental error, the reduction and hydrolysis procedures were performed in the same test tube. The samples were dried using a rotary evaporator and residual acid was removed by re-dissolving the residue in $200 \mu 1$ of distilled water, drying again, and finally dissolving in $500 \mu \mathrm{l}$ distilled water. A $350 \mu \mathrm{l}$ aliquot was added to $350 \mu \mathrm{l}$ of HEPES buffer $(100 \mathrm{mmol} / \mathrm{l}$ HEPES, $20 \mathrm{mmol} / \mathrm{I} \mathrm{MgCl}_{2}, \mathrm{pH} 8.5$ ) and applied to an affinity column. Disposable polystyrene columns $(8 \times 120 \mathrm{~mm}$, Pierce Chemical Company, Rockford, Ill, USA) containing $2 \mathrm{ml}$ of m-aminophenyl boronic acid affinity resin (Matrex Gel PBA-60, Amicon Corp., Danvers, Mass, USA) were used, and were equilibrated at $\mathrm{pH} 8.5$ with $50 \mathrm{mmol} / 1$ HEPES $/ 10 \mathrm{mmol} / 1 \mathrm{MgCl}_{2}$ buffer, as recommended by the manufac- turer. After application of the sample, the column was washed with five column volumes of HEPES buffer, after which radioactivity in the eluate was less than three times background. Hexitol-amino-acid was eluted using three $2 \mathrm{ml}$ aliquots of $0.1 \mathrm{~mol} / \mathrm{l}$ acetic acid. Tritium radioactivity in these washes was counted to estimate the relative content of hexitol-amino-acid in the various samples.

To quantitate the amount of hydrolysed apolipoprotein or plasma protein applied to the affinity column, the free amino-group content of each hydrolysate was measured, in triplicate, by the trinitrobenzenesulfonic acid (TNBS) method [12, 13]. The assay was standardised using a known quantity of LDL, hydrolysed under identical conditions, and the result expressed as $\mu \mathrm{g}$ of hydrolysed protein.

The extent of glycosylation of LDL or plasma protein was expressed as counts per min. ${ }^{3} \mathrm{H}$-hexitol-amino-acid radioactivity per $\mu \mathrm{g}$ hydrolysed protein. The results reported here were obtained from five separate experiments conducted over a 2 week period. In every case both members of a diabetic-control pair were studied in the same experiment, and the same batch of tritiated sodium borohydride was used throughout. The between-assay coefficient of variation for the whole procedure was $10.8 \%(n=6)$; and the within-assay variation was $7.8 \%$ for $\mathrm{LDL}$ and $7.1 \%$ for plasma proteins.

\section{Other methods}

Home blood glucose measurements were obtained and recorded by the patients using Dextrostix and a Glucometer (Ames Division, Miles Laboratories Inc., Elkhart, Ind, USA). Plasma glucose was assayed using the glucose oxidase method, as adapted for use in the Beckman glucose analyser [14]. $\mathrm{HbA}_{1 \mathrm{c}}$ was measured by isoelectric focusing of erythrocyte hemolysates in a gradient of $\mathrm{pH} 6-8$ [15].

Plasma total cholesterol and total triglyceride were measured by the semi-automated methods standardised by the Lipid Research Clinics Program [16]. The cholesterol content of LDL and VLDL was obtained using the above methodology after separation of the lipoproteins by ultracentrifugation as previously described [17]. HDL cholesterol was measured in whole plasma after precipitation of VLDL and LDL with sodium phosphotungstate/magnesium chloride as previously described [18].

\section{Statistical analysis}

Statistical analysis was performed using the paired Student's t-test to compare differences between paired data. Correlation coefficients were determined by linear regression analysis [19]. All results are expressed as mean $\pm \mathrm{SEM}$.

\section{Results}

A significant correlation was found between LDL glycosylation and plasma protein glycosylation $(p<0.001$, Fig. 1). The 11 patients who performed home blood glu- 


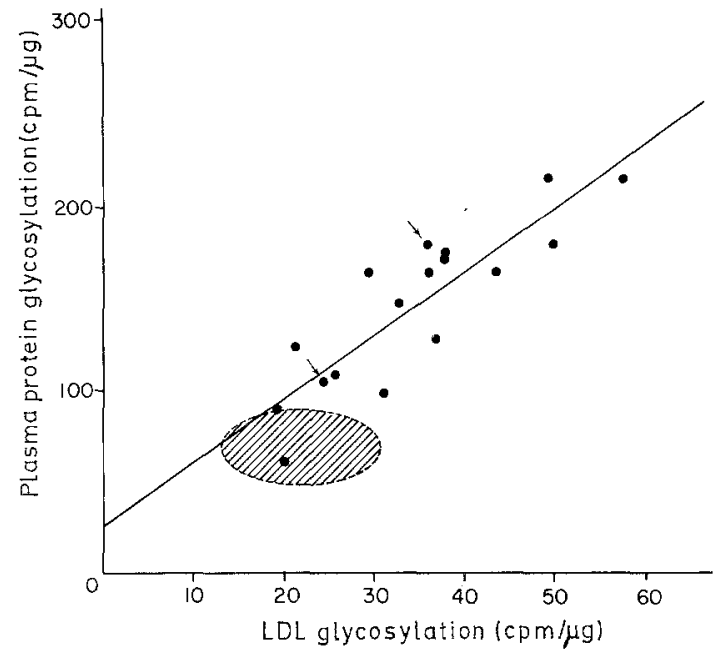

Fig. 1. Relationship between LDL glycosylation and plasma protein glycosylation in 16 diabetic patients $(y=3.5 x+26.0, r=0.86)$. Ellipse indicates mean $\pm 1 \mathrm{SD}$ for corresponding controls. Arrows indicate results obtained from same patient on two separate occasions

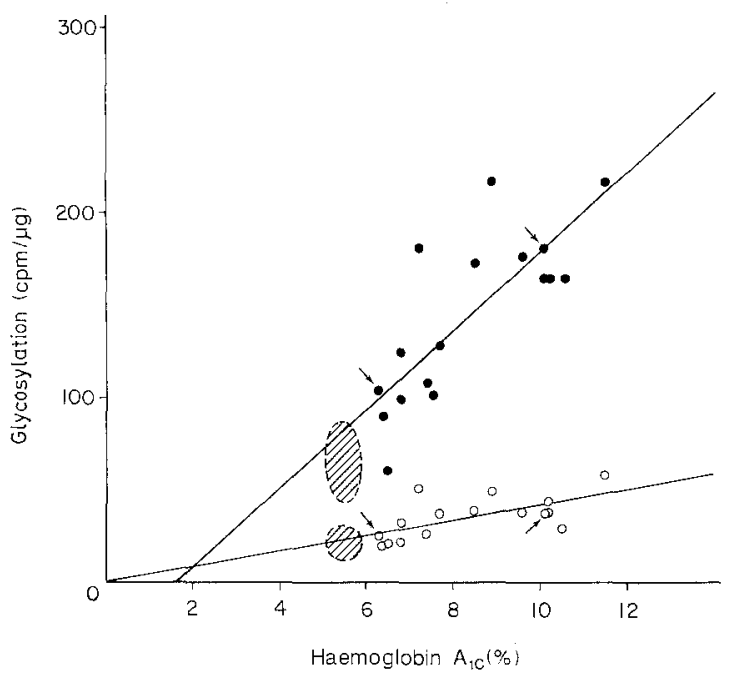

Fig. 3. Relationship of $\mathrm{HbA}_{1 \mathrm{c}}$ to LDL glycosylation (o) $(y=$ $4.2 x-0.4, \quad r=0.64)$ and plasma protein glycosylation $(\bullet)(y=$ $21.3 x-34.2, r=0.79)$ in 16 diabetic patients. Ellipses indicate mean $\pm 1 S D$ for corresponding controls. Arrows indicate results obtained from same patient on two separate occasions

cose monitoring reported an average of 24 readings each in the week preceding blood sampling. Both LDL glycosylation and plasma protein glycosylation were significantly correlated with mean home blood glucose $(p<0.01$ and $p<0.001$ respectively, Fig. 2$)$. Similarly, LDL glycosylation and plasma protein were significantly correlated with $\mathrm{HbA}_{1 \mathrm{c}}(p<0.01$ and $p<0.001$ respectively, Fig.3).

Glycosylation of LDL and of plasma proteins was significantly higher in diabetic patients than in control subjects $(p<0.001$, Table 2$)$. As expected, fasting plasma glucose and $\mathrm{HbA}_{1 \mathrm{c}}$ levels were significantly higher

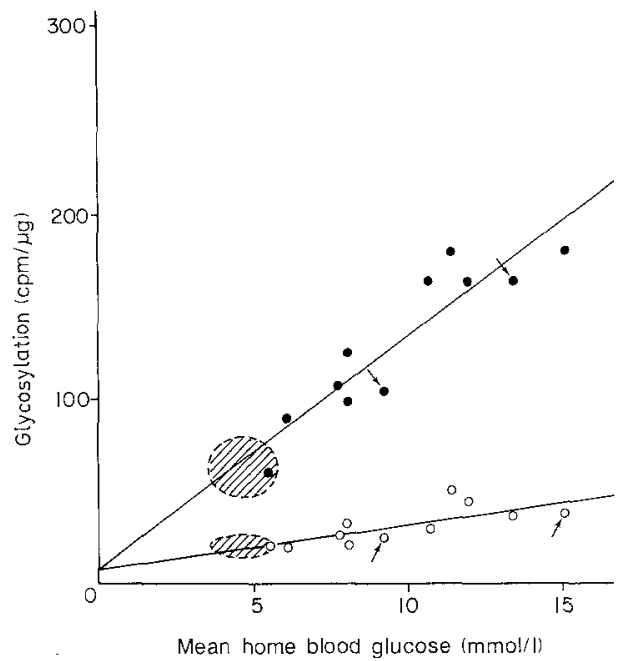

Fig. 2. Relationship of mean home blood glucose to LDL glycosylation (o) $(y=2.4 x+7.0, r=0.73)$ and plasma protein glycosylation $(\bullet)$ $(y=12.2 x+7.6, r=0.91)$ in 11 diabetic patients. Ellipses indicate mean $\pm 1 \mathrm{SD}$ for corresponding controls. Arrows indicate results obtained from same patient on two separate occasions

in diabetic patients than in control subjects (Table 2). The values indicate that the majority of patients was in good or fair glycaemic control.

Plasma lipid levels in the diabetic and control groups are shown in Table 3. There were no significant differences between the two groups in total triglycerides, total cholesterol or in the cholesterol content of LDL, VLDL or HDL.

\section{Discussion}

Our study demonstrates increased glycosylation of LDL in a group of normolipaemic Type 1 diabetic patients in good to fair glycaemic control. The findings are consistent with those of Schleicher et al. [20], and Witztum et al. [5], who found similar increases in glycosylation of LDL in diabetes but did not provide details of lipid levels or glycaemic control in the patients they studied. In contrast, Curtiss and Witztum [21], using an immunochemical method, found a much greater increase in apo-B glycation in three severely hyperglycaemic, hyperlipidaemic diabetic patients. LDL glycation in our diabetic patients was increased 1.6-fold over control values, a similar increase to that found for haemoglobin (1.5-fold) and plasma proteins (2.2-fold). However, we observed that, in both diabetic patients and control subjects, LDL glycosylation was lower than plasma protein glycosylation (Table 2). This may be partly because LDL apolipoprotein has a shorter circulating half-life (approximately 3 days [22]) than the majority of plasma proteins (albumin, 17-23 days; $\gamma$-globulin, 15-26 days [23]). The apolipoprotein component, being partially embedded in the lipoprotein particle, may also be less accessible than other proteins to free glucose. We found significant correlations between 
Table 2. Parameters of glycaemic control in diabetic and control groups

\begin{tabular}{|c|c|c|c|c|c|}
\hline & $\begin{array}{l}\text { FPG } \\
(\mathrm{mmol} / \mathrm{l})\end{array}$ & $\begin{array}{l}\text { MHBG } \\
(\mathrm{mmol} / \mathrm{l})\end{array}$ & $\begin{array}{l}\mathrm{HbA}_{1 \mathrm{c}} \\
(\%)\end{array}$ & $\begin{array}{l}\text { Gly-PP } \\
{ }^{3} \mathrm{H}-\mathrm{HAA} \\
\text { cpm/ } / \mathrm{g}\end{array}$ & $\begin{array}{l}\text { Gly-LDL } \\
{ }^{3} \mathrm{H}-\mathrm{HAA} \\
\mathrm{cpm} / \mu \mathrm{g}\end{array}$ \\
\hline $\begin{array}{l}\text { Control subjects } \\
(n=16)\end{array}$ & $\begin{array}{c}4.6 \pm 0.1 \\
(3.9-5.6) \\
\end{array}$ & - & $\begin{array}{c}5.6 \pm 0.1 \\
(5.3-6.0)\end{array}$ & $\begin{array}{r}65.9 \pm 2.6 \\
(48-84)\end{array}$ & $\begin{array}{c}22.1 \pm 1.0 \\
(17.2-33.3)\end{array}$ \\
\hline
\end{tabular}

FPG - fasting plasma glucose; MHBG - mean home blood glucose; Gly-PP - glycosylated plasma proteins, Gly-LDL - glycosylated LDL; ${ }^{3} \mathrm{H}-\mathrm{HAA}$ - tritiated hexitol-amino-acid. Values indicate mean \pm SEM (range) of $17 \mathrm{observations} \mathrm{(one} \mathrm{patient/control} \mathrm{pair} \mathrm{studied} \mathrm{twice).}$

${ }^{a} n=11$

Table 3. Plasma lipid levels in diabetic and control groups

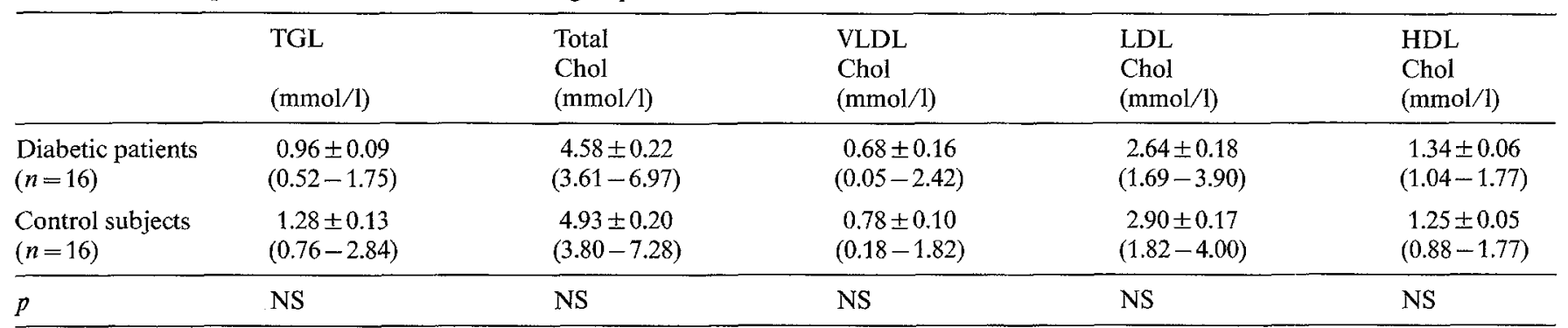

TGL - triglycerides; Chol - cholesterol; values shown indicate mean \pm SEM (range) of 17 observations (one patient/control pair studied twice); $\mathrm{NS}=$ not significant

LDL glycosylation and three other parameters of glycaemic control - glycosylation of plasma proteins, mean home blood glucose concentration, and haemoglobin $\mathrm{A}_{1 \mathrm{c}}$. Glycosylation of LDL was more closely correlated with plasma protein glycosylation and with mean home blood glucose than with haemoglobin $A_{1 c}$, possibly because the latter reflects glycaemic control over a longer period of time.

We used boronate affinity chromatography to measure LDL glycosylation. This method has the advantage of being highly specific; only compounds with co-planar cis-hydroxyl groups will form stable complexes with the boronate gel under alkaline conditions. Of the compounds resulting from the reduction and hydrolysis of LDL, only glycosylated amino acids contain this structural conformation. The method has the additional advantage, particularly important in work with lipoproteins, of requiring only small quantities of protein. We must emphasize the importance of thorough removal of glucose from the LDL samples prior to the assay, since glucitol binds effectively to the boronate gel and therefore can cause interference. Furthermore, we recommend that freezing of LDL samples should be avoided if possible - in this study sonication was necessary to disperse agglutinated lipoprotein after thawing.

The hypothesis that an increase in LDL glycosylation, to the extent occuring in diabetic patients in good or fair glycaemic control, may be important in the pathogenesis of atherosclerosis is supported by recent studies in our laboratory. We have shown that LDL gly- cosylated in vitro increases cholesteryl ester (CE) synthesis and $\mathrm{CE}$ accumulation in human macrophages [24]. Macrophages are thought to be the main precursors of foam cells which are characteristic of the early atheromatous plaque. We have also demonstrated increased CE synthesis in macrophages exposed to LDL isolated from a small group of normolipaemic diabetic patients, and found a significant correlation between CE synthesis and LDL glycosylation [25]. These findings may help to explain why the diabetes, irrespective of type [26, 27], is an independent risk factor in the development of atherosclerosis. They may also have relevance to the observation that lesser degrees of hyperglycaemia may be associated with an increased risk of vascular disease $[28,29]$.

In conclusion, our study demonstrates the presence of increased glycosylation of LDL in a group of relatively well-controlled Type 1 diabetic patients, and it is possible that this increase may accelerate the development of atherosclerosis. The extent of LDL glycosylation correlates well with commonly used indices of glycaemic control and our findings, therefore, provide further evidence that optimal glycaemic control is an important goal in the management of all diabetic patients.

Acknowledgements. This work was performed while Dr. Lyons was the recipient of a Clinical Research Fellowship from the College of Graduate Studies, Medical University of South Carolina. The authors wish to thank Dr. R. K. Mayfield for his assistance in patient recruitment, and the staff of the Special Diagnostic and Treatment Unit, 
VAMC, Charleston. Expert laboratory assistance was provided by Mr. L. Long and Ms. V. Waldrop, VAMC, Charleston. This work was supported by the Research Service of the Veterans Administration Medical Center and by the National Institutes of Health Grants AM10071 (JWB) and HL 30929 (MFL-V). Dr. Lopes-Virella is a VA Clinical Investigator. Secretarial assistance was provided by Ms. S. Tant.

\section{References}

1. Nomenclature Committee of IUB, Joint Commission on Biochemical Nomenclature (1984) Newsletter Biochem J 217: I-IV

2. Kennedy L, Baynes JW (1984) Nonenzymatic glycosylation and the chronic complications of diabetes: an overview. Diabetologia 26: $93-98$

3. Entmacher PS, Krall LP, Kranczer SN (1985) Diabetes mortality from vital statistics. In: Marble A, Krall LP, Bradley RF, Christlieb AR, Soeldner JS (eds) Joslin's diabetes mellitus, 12th edn. Lea and Febiger, Philadelphia, pp 278-297

4. Gonen B, Baenziger J, Schonfeld G, Jacobson D, Farrar P (1981) Nonenzymatic glycosylation of low density lipoproteins in vitro. Diabetes 30: $875-878$

5. Witztum JL, Mahoney EM, Branks MJ, Fisher M, Elam R, Steinberg D (1982) Nonenzymatic glucosylation of low density lipoprotein alters its biologic activity. Diabetes $31: 283-291$

6. Steinbrecher UP, Witztum JL (1984) Glucosylation of low-density lipoproteins to an extent comparable to that seen in diabetes slows their catabolism. Diabetes 33: 130-134

7. National Diabetes Data Group (1979) Classification and diagnosis of diabetes mellitus and other categories of glucose intolerance. Diabetes 28: 1039-1057

8. Havel RJ, Eden HA, Bragdon JH (1955) The distribution and chemical composition of ultracentrifugally separated lipoproteins in human serum. $\mathbf{J}$ Clin Invest 34: 1345-1353

9. Lowry OH, Rosebrough NJ, Farr AL, Randall BJ (1951) Protein measurement with the Folin phenol reagent. J Biol Chem 193: 265-275

10. Yue DK, McLennan S, Turtle JR (1981) Non-enzymatic glycosylation of tissue protein in diabetes in the rat. Diabetologia 24: $377-381$

11. Baynes JW, Thorpe SR, Murtiashaw MH (1984) Nonenzymatic glucosylation of lysine residues in albumin. Methods Enzymol 106: 88-98

12. Fields $R$ (1971) The measurement of amino groups in proteins and peptides. Biochem J 124: 581-590

13. Snyder SL, Sobocinski PZ (1975) An improved 2,4,6-Trinitrobenzenesulfonic acid method for the determination of amines. Anal Biochem 64: 284-288

14. Kadish AH, Little RL, Steinberg JC (1968) A new and rapid method for the determination of glucose by measurement of rate of oxygen consumption. Clin Chem 14: 116-131

15. Spicer KN, Allen RC, Buse MG (1978) A simplified assay of hemoglobin $A_{1 c}$ in diabetic patients, using isoelectric focusing and quantitative microdensitometry. Diabetes $27: 384-388$
16. Department of Health, Education and Welfare (1974) Manual of lipid operations. Lipid Research Clinics Program, Vol 1. Lipid and lipoprotein analysis, NHLI, NIH, Bethesda, Maryland, Publ No (NIH) $75-628$

17. Lopes-Virella MF, Sherer GK, Lees AM, Wohltmann H, Mayfield RK, Sagel J, Leroy EC, Colwell JA (1982) Surface binding, internalization and degradation by cultured human fibroblasts of lowdensity lipoproteins isolated from type 1 (insulin-dependent) diabetic patients: changes with metabolic control. Diabetologia 22: 430-436

18. Lopes-Virella MF, Stone P, Ellis S, Colwell JA (1977) Cholesterol determination in high density lipoproteins separated by three different methods. Clin Chem 23: 882-884

19. Zar JH (1984) Biostatistical analysis. Prentice-Hall Inc., Englewood Cliffs, NJ

20. Schleicher E, Deufel T, Wieland OH (1981) Non-enzymatic glycosylation of human serum lipoproteins. FEBS Lett 129:1 -4

21. Curtiss LK, Witztum JL (1985) Plasma apolipoproteins AI, AII, B, $\mathrm{CI}$, and $\mathrm{E}$ are glucosylated in hyperglycemic diabetic subjects. Diabetes 34: 452-461

22. Gitlin D, Cornwell DG, Nakasato D, Oncley JL, Hughes WL, Jr, Janeway CA (1958) Studies on the metabolism of plasma proteins in the nephrotic syndrome. (II. The lipoproteins). J Clin Invest 37: 172-184

23. Schultze HE, Heremans JF (1966) Molecular biology of human proteins, Vol 1. Elsevier, Amsterdam, p 476

24. Lopes-Virella MF, Klein RL, Lyons TJ, Stevenson HC, Witztum JL (1986) Metabolism of in vitro glucosylated LDL (Glu-LDL) by human monocyte-derived macrophages. Diabetes 35 (Suppl 1): $89 \mathrm{~A}$

25. Lyons TJ, Klein RL, Baynes JW, Lopes-Virella MF (1986) Stimulation of cholesteryl ester (CE) synthesis in human monocytederived macrophages by LDL isolated from diabetic patients. Clin Res 34: 208a

26. Garcia MJ, McNamara PM, Gordon T, Kannell WB (1974) Morbidity and mortality in diabetics in the Framingham population. Diabetes 23: 105-111

27. Kannel WB, McGee DL (1979) Diabetes and cardiovascular disease. The Framingham Study. JAMA 241: 2035-2038

28. Jarrett RJ, McCartney P, Keen H (1982) The Bedford Survey: ten year mortality rates in newly diagnosed diabetics, borderline diabetics and normoglycaemic controls and risk indices for coronary heart disease in borderline diabetics. Diabetologia 22:79-84

29. Fuller JH, Shipley MJ, Rose G, Jarrett RJ, Keen H (1980) Coronary heart disease risk and impaired glucose tolerance - The Whitehall Study. Lancet 1: 1373-1376

Received: 11 February 1986

and in revised form: 11 August 1986

Dr. Maria F. Lopes-Virella

VA Medical Center

109 Bee Street

Charleston, South Carolina 29425

USA 